\title{
Performance of Rice Husk Ash Concrete in Sulfate Solutions
}

\author{
Ash Ahmed* and John Kamau \\ Civil Engineering Group, UK \\ *Corresponding author: Ash Ahmed, Civil Engineering Group, UK

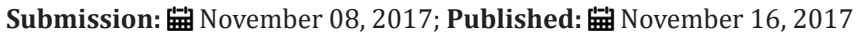

\begin{abstract}
Durability of concrete is defined as its ability to resist deterioration after exposure to the environment of its use. This work examined the performance of Rice Husk Ash (RHA) concrete in sodium sulfate $\left(\mathrm{Na}_{2} \mathrm{SO}_{4}\right)$, magnesium sulfate $\left(\mathrm{MgSO}_{4}\right)$ and combined $\mathrm{Na}_{2} \mathrm{SO}_{4}$ and $\mathrm{MgSO}_{4}$ solutions. Concrete bar specimens and cubes were prepared for elongation and strength deterioration tests respectively using RHA replacement at the 7.5\% replacement by volume, which had achieved the highest compressive strength from a previous study, as well as at the $30 \%$ replacement by volume, which was the highest replacement for the study. Strength deterioration tests were performed on the $7.5 \%$ replacement by the weight of cement. From the elongation findings, it was concluded that at the $7.5 \%$ replacement, RHA could be used with an advantage over $100 \%$ cement concrete in $\mathrm{MgSO}_{4}$ environments, whereas at the $30 \%$ replacement, RHA could be used with an advantage over $100 \%$ cement concrete in both the $\mathrm{Na}_{2} \mathrm{SO}_{4}$ and mixed sulfate environments For strength deterioration, the findings show that RHA could be used in both the $\mathrm{Na}_{2} \mathrm{SO}_{4}$ and mixed sulfate environments with an advantage over the $100 \%$ cement. RHA was also found to be more effective in resisting surface deterioration in all the sulfate solutions.
\end{abstract}

Keywords: Rice husk ash; Deterioration of concrete; Sulfate attack

\section{Introduction}

Durability of concrete is defined as its ability to resist deterioration, thereby being capable of maintaining its original quality and form once it has been exposed to the environment of its use [1]. The deterioration of concrete can be caused by either internal chemical reaction from the constituents of concrete or external attacks from chemicals such as sulfates [1]. This study focuses on sulfate attack, which is a major cause of the lack of durability in concrete.

One of the results of sulfate attack on concrete is the loss of strength by affecting calcium hydroxide $\left[\mathrm{Ca}(\mathrm{OH})_{2}\right]$, the product of the hydration of cement, and the strength giving Calcium Silicate Hydrate (C-S-H), the product of the reaction between $\mathrm{Ca}(\mathrm{OH})_{2}$ and silicone dioxide $\left(\mathrm{SiO}_{2}\right)$ [2]. Gypsum and expansive ettringite are formed when Sodium sulfate $\left(\mathrm{Na}_{2} \mathrm{SO}_{4}\right)$ attacks $\mathrm{Ca}(\mathrm{OH})_{2}$ [2]. Ettringite, which grows as needle shaped crystals causes volume increases of up to $126 \%$ depending on exposure conditions, and can generate very high stresses, which if higher than the tensile strength of concrete can bring about cracking [2].

Decalcification of C-S-H in $\mathrm{Na}_{2} \mathrm{SO}_{4}$ attack to cause loss of strength is negligible, and for this reason, it has been suggested that $\mathrm{Na}_{2} \mathrm{SO}_{4}$ attack manifests and should be evaluated through expansion. On the other hand, Magnesium sulfate $\left(\mathrm{MgSO}_{4}\right)$ attack has been reported to affect C-S-H, converting it to Magnesium Silicate Hydrate (M-S-H), which is not cementitious. For this reason also, it has been reported that $\mathrm{MgSO}_{4}$ attack should be evaluated through the loss of strength of concrete [2].

It has been posited that low sulfate resistance is caused by low levels of silicone dioxide $\left(\mathrm{SiO}_{2}\right)$, and high levels of sulfate $\left(\mathrm{SO}_{4}\right)$, iron $\left(\mathrm{Fe}_{2} \mathrm{SO}_{3}\right), \mathrm{Ca}(\mathrm{OH})_{2}$, and aluminate $\left(\mathrm{C}_{3} \mathrm{~A}\right)$ [3]. It has also been reported that a high molar ratio of sulfite $\left(\mathrm{SO}_{3}\right)$ to aluminium oxide $\left(\mathrm{Al}_{2} \mathrm{O}_{3}\right)$ enhances the formation of monosulfate, which leads to the formation of ettringite and gypsum on exposure to sulfate attack [2].

It has also been suggested that the reaction between Supplementary Cementitious Materials (SCMS) such the RHA and cement, which is also known as the pozzolanic reaction helps to dilute $\mathrm{C} 3 \mathrm{~A}$ and remove $\mathrm{Ca}(\mathrm{OH})_{2}$ by converting it into $\mathrm{C}-\mathrm{S}-\mathrm{H}$, hence reducing the quantities of gypsum formed. A poor performance of SCMs in $\mathrm{Mg}(\mathrm{SO})_{4}$ solutions has however been reported, since $\mathrm{Mg}(\mathrm{SO})_{4}$ mainly affects $\mathrm{C}-\mathrm{S}-\mathrm{H}$, resulting in the loss of strength, [2]. Elsewhere, literature has it that permeability, which is defined as the rate at which pressured water can flow through interconnected voids within concrete, or the measure of how easily a liquid or gas can get through concrete, is the most important aspect of durability, since it slows down the flow of harmful substances into concrete $[4,5]$. In as much as controlling the chemistry of concrete is vital as discussed above, it is more important to maintain low permeability [6]. SCMs reduce the permeability of concrete by the packaging effect of their unreacted particles, as well as by the help of the 
C-S-H that is formed as a result of their use, whose benefit is a less well interconnected capillary pore structure, that leads to lower permeability $[2,7]$.

Table 1: Largest rice producing countries in the world [9].

\begin{tabular}{|c|c|c|}
\hline Rank & Country & Rice produced (millions of hectares) \\
\hline 1 & India & 43.2 \\
\hline 2 & China & 30.4 \\
\hline 3 & Indonesia & 12.2 \\
\hline 4 & Bangladesh & 12.0 \\
\hline 5 & Thailand & 9.7 \\
\hline 6 & Vietnam & 7.7 \\
\hline 7 & Burma & 6.8 \\
\hline 8 & Philippines & 4.5 \\
\hline 9 & Cambodia & 2.9 \\
\hline 10 & Pakistan & 2.9 \\
\hline
\end{tabular}

It has further been suggested that the compressive strength of concrete is directly proportional to its durability, with low compressive strengths spelling low durability and vice versa $[4,8]$. RHA was defined by [2] as the product of incinerated rice husk, which is the outer shell that covers the rice kernel, the product of threshed paddy to separate rice grain and the husk. Its suitability as a SCM was investigated by Kamau et al. [9] who evaluated the strength of concrete using untreated rice husk ash as a partial cement replacement up to $30 \%$ substitution; their findings found each mix satisfied the $\mathrm{C} 32 / 40$ strength class at 91 days thus proving the potential pozzolanic qualities of RHA. Over 2 million tonnes of rice are produced every year all over the world, with Asia being the largest producer as is shown in Table 1 [9]. Rice husk, the outer shell that covers the rice kernel, is a product of threshed paddy to separate rice grain and the husk; over 600 million tonnes of paddy were produced in the year 2008 [9]. Paddy is of very low nutrition to even be suitable for animal feed, but of all plant residues, it contains the highest amount of silica. RHA is obtained from either controlled or uncontrolled incineration of rice husks [9].

\section{Research Significance}

Some work has been carried out on the performance of RHA mortar in sulfate solutions. However, no work was found on the performance of RHA-replaced concrete. This work tested concrete bar specimens made from RHA replacement.

\section{Previous Data}

\section{Chemical composition}

Table 2: Chemical composition of RHA [9].

\begin{tabular}{|c|c|c|}
\hline \multirow{2}{*}{ Chemical } & \multicolumn{2}{|c|}{ Percentage Composition } \\
\cline { 2 - 3 } & Cement & RHA \\
\hline Silicon dioxide $\left(\mathrm{SiO}_{2}\right)$ & 21.9 & 87.8 \\
\hline Aluminium oxide $\left(\mathrm{Al}_{2} \mathrm{O}_{3}\right)$ & 4.0 & 0.4 \\
\hline Iron oxide $\left(\mathrm{Fe}_{2} \mathrm{O}_{3}\right)$ & 0.2 & 0.3 \\
\hline Calcium oxide $(\mathrm{CaO})$ & 66.5 & 0.7 \\
\hline Magnesium oxide $(\mathrm{MgO})$ & 1.4 & 0.6 \\
\hline Sodium oxide $\left(\mathrm{Na}_{2} \mathrm{O}\right)$ & 0.1 & 0.5 \\
\hline Potassium oxide $\left(\mathrm{K}_{2} \mathrm{O}\right)$ & 0.6 & 2.2 \\
\hline Loss on ignition $(\mathrm{LOI})$ & - & 2.2 \\
\hline Sulphur trioxide $\left(\mathrm{SO}_{3}\right)$ & 2.6 & 0.1 \\
\hline
\end{tabular}

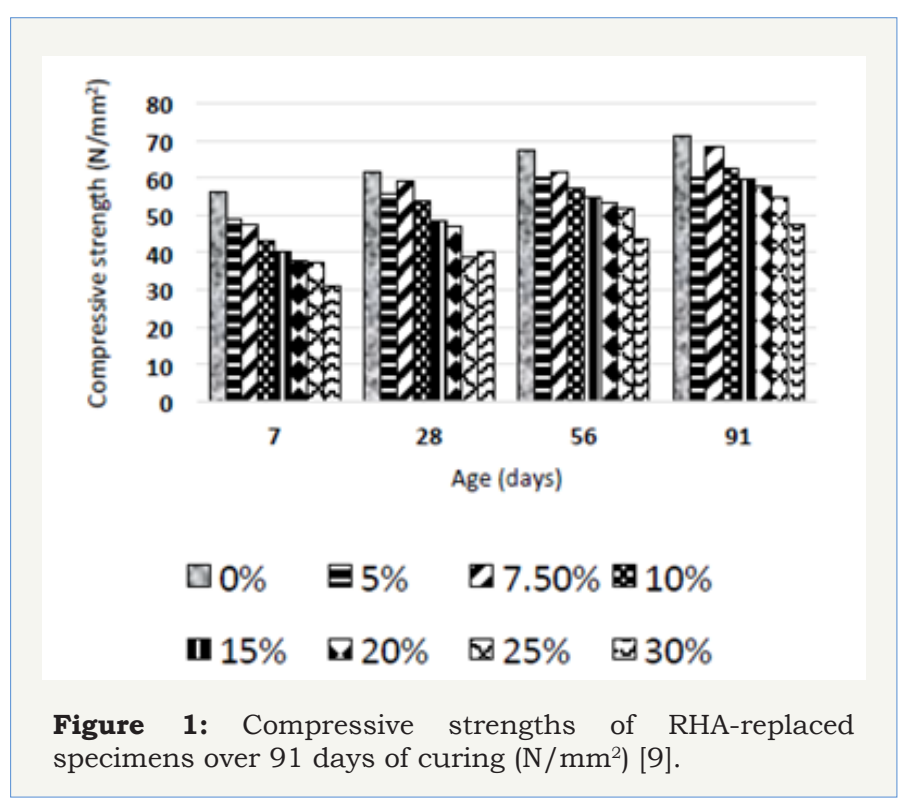

Table 2 shows the chemical composition of cement and RHA obtained by, whereas Table 3 and Figure 1 show the compressive strengths that were obtained by [9]. Since levels of $\mathrm{Fe}_{2} \mathrm{O}_{3}$ are low, and those of $\mathrm{SiO}_{2}$ are high, it may be concluded that RHA could have a high resistance to sulfate attack, since also the ratio of $\mathrm{SO}_{3}$ to $\mathrm{Al}_{2} \mathrm{O}_{3}$ which was also reported by [2] to enhance sulfate attack when high was also low. The compressive strengths obtained by [9] were among those listed by [10] as being suitable for structural applications and durable (Table 3). 
Table 3: Compressive strengths of RHA-replaced specimens over 91 days of curing $\left(\mathrm{N} / \mathrm{mm}^{2}\right)$.

\begin{tabular}{|c|c|c|c|c|c|c|c|c|}
\hline $\begin{array}{c}\text { Age } \\
\text { (days) }\end{array}$ & $\mathbf{0 \%}$ & $\mathbf{5 \%}$ & $\mathbf{7 . 5 \%}$ & $\mathbf{1 0 \%}$ & $\mathbf{1 5 \%}$ & $\mathbf{2 0 \%}$ & $\mathbf{2 5 \%}$ & $\mathbf{3 0 \%}$ \\
\hline 7 & 56.2 & 49 & 47.4 & 43.1 & 40.1 & 37.8 & 37.1 & 31.2 \\
\hline 28 & 61.6 & 56 & 59.1 & 54 & 48.4 & 46.9 & 38.6 & 40.1 \\
\hline 56 & 67.6 & 60.1 & 61.5 & 57.1 & 54.9 & 53.5 & 51.9 & 43.9 \\
\hline 91 & 71.3 & 60 & 68.3 & 62.7 & 59.6 & 57.7 & 54.8 & 47.5 \\
\hline
\end{tabular}

Table 4: Coefficient of water absorption of RHA replaced specimens [C w.s $\left.\left(\mathrm{g} / \mathrm{m}^{2} . \mathrm{s}\right)\right][11]$.

\begin{tabular}{|c|c|c|c|}
\hline $\begin{array}{c}\text { Highest } \\
\text { Compressive } \\
\text { Strength }\end{array}$ & $\begin{array}{c}\text { Coefficient } \\
\text { of Water } \\
\text { Absortion [C } \\
\left.\text { w.s }\left(\mathrm{g} / \mathrm{m}^{2} . \mathbf{s}\right)\right]\end{array}$ & $\begin{array}{c}30 \% \\
\text { Replacement }\end{array}$ & $\begin{array}{c}\text { Coefficient } \\
\text { of Water } \\
\text { Absortion [C w.s } \\
\left.\left(\mathrm{g} / \mathrm{m}^{2} . \mathbf{s}\right)\right]\end{array}$ \\
\hline $\begin{array}{l}\text { Control }(0 \% \\
\text { RHA) }\end{array}$ & 0.5767 & Control & 0.5767 \\
\hline $7.5 \%$ RHA & 0.5075 & $30 \%$ RHA & 0.7583 \\
\hline
\end{tabular}

The permeability of RHA replaced specimens was reported by [11] and is shown in Table 4. From the results, a conclusion from the assumptions of $[4,8]$ that compressive strength is directly proportional to durability could be arrived at, as lower permeability was reported at highest compressive strength as opposed to the highest replacement.

\section{Methods}

Sulfate tests were carried out conforming to [12]. Using a mix proportion of 1:2:3, $100 \mathrm{~mm} \times 100 \mathrm{~mm} \times 100 \mathrm{~mm}$ cubes and $160 \mathrm{~mm} \times 40 \mathrm{~mm} \times 40 \mathrm{~mm}$ bars were cast. The cubes, which were used to test for strength deterioration, were made using $7.5 \%$ RHA replacement by the weight of cement, whereas the bars for elongation were made using $7.5 \%$ RHA replacement by the volume of cement.

The specimens were demolded after having been placed in an oven for $231 / 2$ hours at $35^{\circ} \mathrm{C}$. Compressive tests were then carried out on two cubes to ensure that the concrete had achieved strengths of not less than $20 \mathrm{~N} / \mathrm{mm}^{2} \pm 1.0 \mathrm{~N} / \mathrm{mm}^{2}$. Sulfate solutions were prepared by mixing water with $5 \% \mathrm{Na}_{2} \mathrm{SO}_{4}, 5 \% \mathrm{MgSO}_{4}$ and mixed $2.5 \% \mathrm{Na}_{2} \mathrm{SO}_{4}+2.5 \% \mathrm{MgSO}_{4}$. The lengths of the bars were taken after which both the bars and cubes were fully immersed in the solutions. A pH of between 7 and 8 was maintained on the solutions throughout the period of immersion. Water was used as the control solution, and was the reference from which performance was measured.

Length measurement was by use of a veneer calipers at weeks $1,2,3,4$, and 8, and at months 4, 8, and 9 conforming to [12] and test results were an average of three specimens conforming to [12]. Tests for elongation were performed on specimens that were reported by [9] to have achieved the highest compressive strength from Table 3 above, which was at the $7.5 \%$ replacement and the $30 \%$ replacement by the volume of cement. This choice of specimens was informed by $[4,8]$ 's assumption that durability is governed by the compressive strength more than it may depend on the amount of SCMs used to improve the chemistry of concrete.

Length change was calculated by using (1), which conformed to [12].

$$
\Delta L=\frac{L_{x}-L_{i}}{L_{g}} * 100
$$

Where:

$\Delta \mathrm{L}=$ percentage change in length at measuring age,

$\mathrm{L}_{\mathrm{x}}=$ Reading of specimen at measuring age,

$\mathrm{L}_{\mathrm{i}}=$ Reading of specimen on immersion,

$\mathrm{L}_{\mathrm{g}}=160$ (nominal length between the innermost ends of the moulds used).

Observations for surface deterioration were done at the end of the 270 days of immersion.

Strength Deterioration Factors (SDFs) were used to asses strength deterioration and were calculated by using (2) after [13].

$$
S D F=\frac{f_{c w^{\prime}}-f_{c s^{\prime}}}{f_{c w^{\prime}}} * 100
$$

Where $\mathrm{f}_{\mathrm{cw}}$ ' is the compressive strength of cube specimens that were immersed in water and $f_{c s}{ }^{\prime}$ is the compressive strength of cubes immersed in sulfate solutions.

\section{Results and Discussions}

\section{Elongation}

Table 5: Percentage elongation of RHA specimens at highest compressive strength $(\mathrm{mm})$.

\begin{tabular}{|c|c|c|c|}
\hline Specimens & $\mathbf{N a}_{2} \mathbf{S O}_{4}$ & $\mathbf{M g S O}_{4}$ & $\begin{array}{c}\mathbf{N a}_{2} \mathbf{S O}_{4} \text { and } \\
\mathbf{M g S O}_{4}\end{array}$ \\
\hline Control (0\%) & 0.0937 & 0.0219 & 0.0750 \\
\hline $7.5 \%$ RHA & 0.7130 & 0.0130 & 1.4190 \\
\hline
\end{tabular}

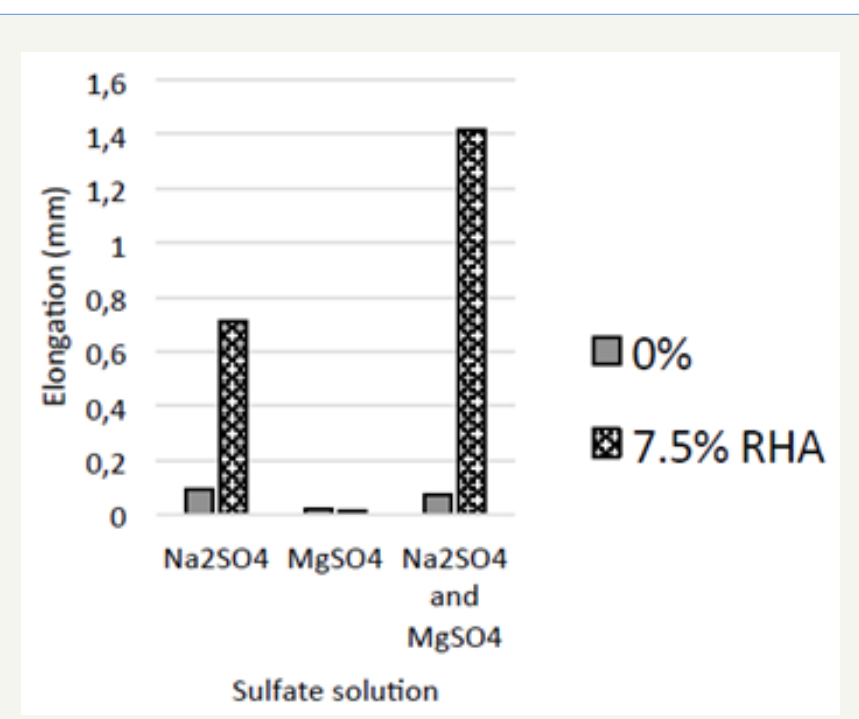

Figure 2: Percentage elongation of RHA specimens at highest compressive strength $(\mathrm{mm})$. 
Table 5 and Figure 2 show the elongation of RHA specimens in $\mathrm{Na}_{2} \mathrm{SO}_{4}, \mathrm{MgSO}_{4}$ and mixed $\mathrm{Na}_{2} \mathrm{SO}_{4}$ and $\mathrm{MgSO}_{4}$ solutions at highest compressive strength.

From the findings, the performance of the RHA specimens was below that of the $0 \%$ RHA specimens (control) in the $\mathrm{Na}_{2} \mathrm{SO}_{4}$ and mixed $\mathrm{Na}_{2} \mathrm{SO}_{4}$ and $\mathrm{MgSO}_{4}$ solutions, whereas in the $\mathrm{MgSO}_{4}$ solution, their performance was above that of the control specimens.

These findings spell that at highest compressive strength, RHA could be used with an advantage over $100 \%$ cement in $\mathrm{MgSO}_{4}$ environments. This may not however necessarily signify high durability in $\mathrm{MgSO}_{4}$ environment since as discussed earlier, deterioration in $\mathrm{MgSO}_{4}$ environments is evaluated through the loss of strength [2]. Moon et al. [13] attributed the slight increase in length in the $\mathrm{MgSO}_{4}$ solution to the formation of brucite, even though [14] reported higher elongations on Silica Fume (SF) replaced specimens immersed in the $\mathrm{MgSO}_{4}$ solution.

Consistent with [13] the RHA specimen's performance in the mixed sulfate solution was poor, a factor which the authors attributed to the predominance of the more aggressive $\mathrm{MgSO}_{4}$ attack. Table 6 and Figure 3 show elongation of RHA specimens in $\mathrm{Na}_{2} \mathrm{SO}_{4}, \mathrm{MgSO}_{4}$ and mixed $\mathrm{Na}_{2} \mathrm{SO}_{4}$ and $\mathrm{MgSO}_{4}$ solutions at the $30 \%$ replacement.

Table 6: Percentage elongation of RHA specimens at $30 \%$ replacement $(\mathrm{mm})$.

\begin{tabular}{|c|c|c|c|}
\hline Specimens & $\mathbf{N a}_{2} \mathbf{S O}_{4}$ & $\mathbf{M g S O}_{4}$ & $\mathbf{N a}_{\mathbf{2}} \mathbf{S O}_{4}$ and $\mathbf{M g S O}_{4}$ \\
\hline Control & 0.4850 & 0.1875 & 0.3500 \\
\hline $30 \%$ RHA & -0.1833 & 0.1833 & 0.4375 \\
\hline
\end{tabular}

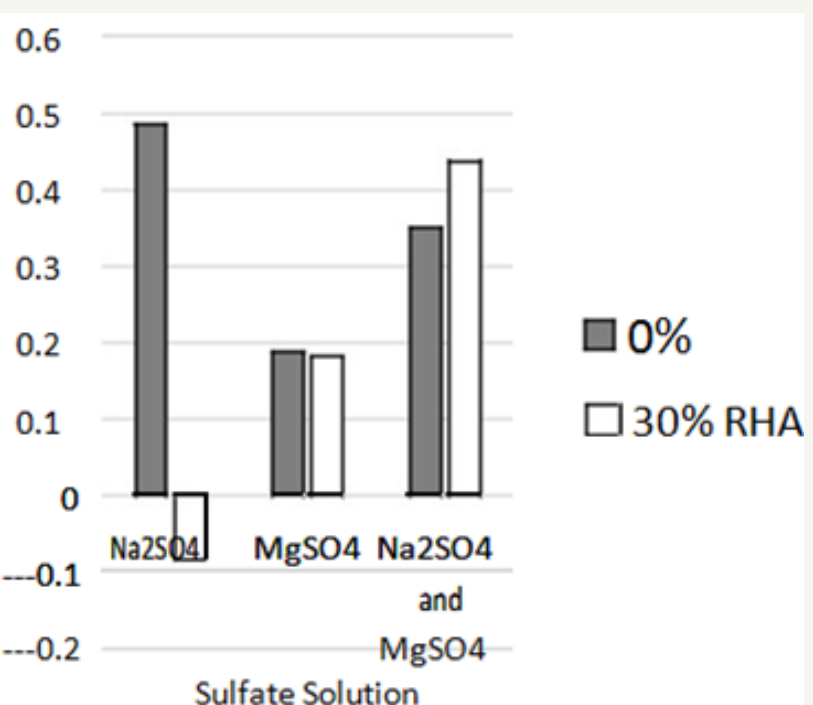

Figure 3: Percentage elongation of RHA specimens at 30\% replacement $(\mathrm{mm})$

From the findings, RHA showed a high performance in the $\mathrm{Na}_{2} \mathrm{SO}_{4}$ solution and a better performance than the control in the
$\mathrm{MgSO}_{4}$ solution, even though its performance in the mixed sulfate solution was below that of the control. These findings are consistent with $[13,15]$, who also reported a better performance than the control on RHA in reducing gypsum and ettringite.

As was earlier on discussed, SCMs aid in resisting sulfate attack as they refine pores, dilute $\mathrm{C}_{3} \mathrm{~A}$ and remove $\mathrm{Ca}(\mathrm{OH})_{2}$ by converting it into $\mathrm{C}-\mathrm{S}-\mathrm{H}$, thereby reducing the quantities of gypsum formed [2]. The results are not however consistent with literature that $\mathrm{MgSO}_{4}$ attack can only manifest in the loss of strength and not in expansion [2], since as earlier on stated, [14] also reported elongation on bars that were immersed in the $\mathrm{MgSO}_{4}$ solution.

Even though [4] reported that low permeability is important as it inhibits the diffusion of harmful substances into the concrete matric, the findings of this study call into question this assumption since from Table 4, [11] reported a lower coefficient of water absorption at the $7.5 \%$ replacement than at the $30 \%$ replacement, and yet the results show a lower expansion at the $30 \%$ replacement than at the $7.5 \%$ replacement in the $\mathrm{Na}_{2} \mathrm{SO}_{4}$ and mixed sulfate solutions.

The results are also not consistent with [2]'s assumptions that the filler effect of unreacted particles improves permeability. Adesanya \& Raheem [1] however attributed the high permeability at high replacements to low levels of $\mathrm{Ca}(\mathrm{OH})_{2}$ available to react with excess SCMs for the formation of the less permeable C-S-H.

\section{Strength deterioration (SDF)}

Table 7: Strength deterioration factors (SDFs) of RHA specimens at 270 days $(\%)$.

\begin{tabular}{|c|c|c|}
\hline & Control & $\mathbf{7 . 5 \%}$ RHA \\
\hline $5 \%$ of $\mathrm{Na}_{2} \mathrm{SO}_{4}$ & 8.6 & 2.6 \\
\hline $5 \%$ of $\mathrm{MgSO}_{4}$ & 17.7 & 27.5 \\
\hline $2.5 \%$ of $\mathrm{Na}_{2} \mathrm{SO}_{4}+2.5 \%$ of $\mathrm{MgSO}_{4}$ & 26.9 & 15.9 \\
\hline
\end{tabular}

As discussed in the methods section, the loss of strength was assessed using Strength Deterioration Factors (SDFs) after [13]. Table 7 shows the SDFs recorded of the RHA specimens immersed in $\mathrm{Na}_{2} \mathrm{SO}_{4}, \mathrm{MgSO}_{4}$ and mixed $\mathrm{Na}_{2} \mathrm{SO}_{4}$, and $\mathrm{MgSO}_{4}$ solutions. The RHA specimens showed lower SDFs than the control specimens in the $\mathrm{Na}_{2} \mathrm{SO}_{4}$ and mixed sulfate solutions.

The findings confirmed literature that $\mathrm{MgSO}_{4}$ attacks C-S-H in SCMs recorded to form the non-cementitious M-S-H, and hence the higher SDFs for the RHA specimens than those of the control specimens in the $\mathrm{MgSO}_{4}$ solution [2]. These results were also consistent with $[16,17]$ who reported lower SDFs than those of the control on CCA and AHS specimens in the $\mathrm{Na}_{2} \mathrm{SO}_{4}$ and mixed sulfate solutions, but higher than those of the control in the $\mathrm{MgSO}_{4}$ solution.

The low SDFs of the RHA specimens in the $\mathrm{Na}_{2} \mathrm{SO}_{4}$ and mixed sulfate solutions spells the possibility of using RHA with an advantage over $100 \%$ cement to improve the performance of 
concrete in these environments.

\section{Surface deterioration}

Table 8: Surface deterioration of RHA specimens in sulfate solutions after [18].

\begin{tabular}{|c|c|c|}
\hline & Control & $\mathbf{7 . 5 \%}$ RHA \\
\hline $5 \%$ of $\mathrm{Na}_{2} \mathrm{SO}_{4}$ & 0 & 0 \\
\hline $5 \%$ of $\mathrm{MgSO}_{4}$ & 0 & 0 \\
\hline $2.5 \%$ of $\mathrm{Na}_{2} \mathrm{SO}_{4}+2.5 \%$ of $\mathrm{MgSO}_{4}$ & 2 & 1 \\
\hline
\end{tabular}

Table 8 shows surface deterioration observed on the RHA specimens immersed in $\mathrm{Na}_{2} \mathrm{SO}_{4}, \mathrm{MgSO}_{4}$ and mixed $\mathrm{Na}_{2} \mathrm{SO}_{4}$ and $\mathrm{MgSO}_{4}$ solutions. The method used by [18] to assess strength deterioration was employed. RHA was observed to improve the surface deterioration of specimens in all the three sulfate solutions over the control specimens. The findings were not consistent with [13] who reported higher surface deterioration on the control specimens than on the $\mathrm{SF}$ specimens in the $\mathrm{Na}_{2} \mathrm{SO}_{4}$ solution.

\section{Conclusion}

This work investigated the performance of RHA replaced concrete in sodium sulfate $\left(\mathrm{Na}_{2} \mathrm{SO}_{4}\right)$, magnesium sulfate $\left(\mathrm{MgSO}_{4}\right)$ and mixed $\mathrm{Na}_{2} \mathrm{SO}_{4}$ and $\mathrm{MgSO}_{4}$ environments. From the findings, the following conclusions were drawn: -

1. At highest compressive strength in elongation, RHA could be used with an advantage over $100 \%$ cement in $\mathrm{MgSO}_{4}$ environments

2. At the $30 \%$ replacement, RHA could be used with an advantage over $100 \%$ cement in $\mathrm{Na}_{2} \mathrm{SO}_{4}$ and $\mathrm{MgSO}_{4}$ environments

3. Strength deterioration results indicate that RHA could be used with an advantage over $100 \%$ cement in $\mathrm{Na}_{2} \mathrm{SO}_{4}$ and $\mathrm{MgSO}_{4}$ environments

4. Surface deterioration results show that RHA could be used with an advantage over $100 \%$ cement in $\mathrm{Na}_{2} \mathrm{SO}_{4}, \mathrm{MgSO}_{4}$ and mixed sulfate environments.

\section{Acknowledgement}

The authors wish to thank the learning officers Kevin and Andy for their assistance with this research.

\section{References}

1. Adesanya D, Raheem A (2010) A study of the permeability and acid attack of corn cob ash blended cements. Construction and Building
Materials 24(3): 403-409.

2. Bapat JD (2012) Mineral admixtures in cement and concrete. CRC Press, USA.

3. Shetty M (2005) Concrete technology: theory and practice. S Chand Group, India.

4. Neville AM, Brooks JJ (1987) Concrete technology. Longman Scientific and Technical. ( $2^{\text {nd }}$ edn), National library of Australia, Australia.

5. Holland TC (2005) Silica fume user's manual: Federal highway administration. Silica Fume Association (SFA), Washington, USA.

6. Mehta P (1992) Sulfate attack on concrete-a critical review. Mater Sci Concr 105.

7. Richardson (2000) The nature of the hydration products in hardened cement pastes. Cement and Concrete Composites 22: 97-113.

8. Arya C (2009) Design of structural elements: concrete, steelwork, masonry and timber designs to British standards and Eurocodes. Spon Press, Taylor \& Francis, London \& Newyork, UK, USA.

9. Kamau, Ahmed A, Hyndman F, Hirst P, Kangwa J (2017) Influence of rice husk ash density on the workability and strength of structural concrete. European Journal of Engineering Research and Science 2(3): 36-43.

10. (2004) British Standards Institution, "BS EN 1992-1-1:2000. Eurocode 2: Design of concrete structures, Part 1-1: General rules and rules for buildings. BSI, London, UK.

11. Kamau J, Ahmed A, Hirst P, Kangwa (2017) Permeability of corncob ash, anthill soil and rice husk ash replaced concrete. International Journal of Science, Environment and Technology 6(2): 1299-1308.

12. American Society for Testing and Materials (ASTM C1012/C1012M-15) (2015) Standard test method for length change of hydraulic-cement mortars exposed to a sulfate solution1. 100 Barr Harbor Drive, PO Box C700, West Conshohocken, PA 19428-2959, USA.

13. Moon HY, Lee ST, Kim SS (2003) Sulphate resistance of silica fume blended mortars exposed to various sulphate solutions. Canadian Journal of Civil Engineering 30(4): 625-636.

14. Park YS, Suh JK, Lee JH, Shin YS (1999) Strength deterioration of high strength concrete in sulfate environment. Cement and concrete research 29(9): 1397-1402.

15. Chindaprasirt P, Kanchanda P, Sathonsaowaphak A, Cao H (2007) Sulfate resistance of blended cements containing fly ash and rice husk ash. Construction and Building Materials 21(6): 1356-1361.

16. Kamau J, Ahmed A, Hirst P, Kangwa J (2016) Suitability of corncob ash as a supplementary cementitious material. International Journal of Materials Science and Engineering 4(4): 215-228.

17. Kamau J, Ahmed A, Hirst P, Kangwa J (2017) Performance of anthill soil replaced concrete in sulfate solutions. European Journal of Engineering Research and Science 2(5): 50-55.

18. Al-Amoudi OSB (1992) Studies on soil-foundation interaction in the sabkha environment of eastern province of Saudi Arabia. Civil Engineering. 